\title{
Outras Políticas para outras Economias: contex- tos e redes na construção de ações do governo federal voltadas à Economia Solidária (2003- 2010)
}

\author{
Gabriela Cavalcanti Cunha \\ Orientador: Christiane Girard-Nunes \\ Tese de Doutorado \\ Data da defesa: 05.04.2012
}

$\mathrm{E}$ sta tese trata das ações do governo federal voltadas à Economia Solidária (ES) no Brasil. O objetivo principal foi examinar, ao longo do período 20032010, dinâmicas institucionais e padrões de interação - tanto no interior do aparelho estatal como no plano das relações Estado-Sociedade - em torno da construção de ações de apoio a organizações econômicas de base associativa e autogestionária. As perguntas de pesquisa giram em torno das formas e conteúdos que essas políticas públicas assumiram, a partir da identificação e análise dos contextos sócio-históricos e das dinâmicas das redes de relações em que se deu sua formulação e implementação. Discuto, inicialmente, que o heterogêneo campo de iniciativas que, gradualmente, se reconheceram sob o termo "Economia Solidária" enfrenta diferentes tipos de invisibilização, limitando que possam ser vistas tanto como realidade objetiva e viva, quanto como objeto da construção de conhecimento, e também como alvo da produção de políticas públicas. Nesse sentido, defendo a importância de "outros olhares" sobre esse campo empírico, em especial articulando contribuições que vêm dos questionamentos ao reducionismo utilitarista, e dos caminhos que se abrem a partir da reemergência do interesse sociológico pelas interações, tornando as abordagens de redes uma espécie de novo paradigma sociológico. Na abordagem do campo empírico, há sobretudo um esforço de detalhar, sistematizar e contextualizar as dinâmicas de interação em torno da construção das políticas de ES em vários espaços, níveis e dimensões de interface, analisando de que modo, em suas respectivas especificidades, constituem no conjunto, o que considerei como um exemplo de "rede de políticas públicas". Para isso, combino elementos tradicionalmente presentes em avaliação de políticas públicas, a partir de fontes de dados primários e secundários, com o levantamento de representações e interações por meio de entrevistas, relatos e observação participante - evidenciando a complementaridade entre procedimentos quantitativos e qualitativos como pressuposto metodológico da pesquisa. 
A partir da análise dos contextos e da rede previamente detalhada, busco refletir sobre alguns dos principais desafios à construção e consolidação de "outras políticas" para "outras economias". Mesmo com as dificuldades e limites identificados para a materialização dos conteúdos contra-hegemônicos e dos pressupostos de participação e transversalidade que norteiam as políticas de ES, os resultados do estudo apontam a abertura de oportunidades ao seu fortalecimento e sustentabilidade em alguns dos espaços formais e informais de interação ao longo do período analisado. Mas isso dependerá tanto de suas dinâmicas internas, quanto das condições externas no horizonte da Economia Solidária no governo federal, reforçando, assim, os desafios aqui levantados.

Palavras-chave: Economia Solidária, Políticas Públicas, Redes (de políticas públicas), Autogestão, Trabalho, Participação, Transversalidade. 